\section{World TB Day — March 24, 2016}

World TB Day is recognized each year on March 24, which commemorates the date in 1882 when Dr. Robert Koch announced his discovery of Mycobacterium tuberculosis, the bacillus that causes tuberculosis (TB). World TB Day is an opportunity to raise awareness about TB and support worldwide TB prevention and control efforts. The U.S. theme for World TB Day, "Unite to End TB," highlights how much more needs to be done to eliminate TB in the United States.

After 2 decades of annual declines, TB incidence in the United States has leveled at approximately 3.0 new cases per 100,000 persons. $(1,2)$. The determinants of this leveling in $\mathrm{TB}$ incidence are not yet clear; further evaluation of available data is required to understand the causes of this trend.

CDC is committed to eliminating TB in the United States. Staying on the path toward TB elimination will require more intensive efforts, both in the United States and globally. These efforts will not only focus on strengthening existing systems for interrupting TB transmission, but also on increasing testing and treatment of persons with latent TB infection. Additional information about World TB Day and CDC's TB elimination activities is available on CDC's website (http://www.cdc.gov/tb/worldtbday).

\section{References}

1. Salinas JL, Mindra G, Haddad MB, Pratt R, Price SF, Langer AJ. Leveling of tuberculosis incidence-United States, 20132015. MMWR Morb Mortal Wkly Rep 2016;65:273-8.

2. CDC. Reported tuberculosis in the United States, 2014. Atlanta, GA: US Department of Health and Human Services, CDC; 2015.

\section{Leveling of Tuberculosis Incidence - United States, 2013-2015}

Jorge L. Salinas, $\mathrm{MD}^{1,2}$; Godwin Mindra, $\mathrm{MBChB}^{1,2}$; Maryam B. Haddad, MSN²; Robert Pratt ${ }^{2}$; Sandy F. Price ${ }^{2}$; Adam J. Langer, DVM ${ }^{2}$

After 2 decades of progress toward tuberculosis (TB) elimination with annual decreases of $\geq 0.2$ cases per 100,000 persons (1), TB incidence in the United States remained approximately 3.0 cases per 100,000 persons during 2013-2015. Preliminary data reported to the National Tuberculosis Surveillance System indicate that TB incidence among foreign-born persons in the United States $(15.1$ cases per 100,000) has remained approximately 13 times the incidence among U.S.-born persons $(1.2$ cases per 100,000). Resuming progress toward TB elimination in the United States will require intensification of efforts both in the United States and globally, including increasing U.S. efforts to detect and treat latent TB infection,

\section{INSIDE}

279 Tuberculosis Among Temporary Visa Holders Working in the Tourism Industry - United States, 2012-2014

282 Photokeratitis Linked to Metal Halide Bulbs in Two Gymnasiums — Philadelphia, Pennsylvania, 2011 and 2013

286 Travel-Associated Zika Virus Disease Cases Among U.S. Residents — United States, January 2015February 2016

290 Preventing Transmission of Zika Virus in Labor and Delivery Settings Through Implementation of Standard Precautions — United States, 2016

293 Notes from the Field: Injuries Associated with Bison Encounters - Yellowstone National Park, 2015

296 QuickStats

Continuing Education examination available at http://www.cdc.gov/mmwr/cme/conted_info.html\#weekly. 
strengthening systems to interrupt $\mathrm{TB}$ transmission in the United States and globally, accelerating reductions in TB globally, particularly in the countries of origin for most U.S. cases.

Health departments in the 50 states and District of Columbia (DC) electronically report verified TB cases that meet the CDC and Council of State and Territorial Epidemiologists case definition to the National Tuberculosis Surveillance System (2). Reports include the patient's demographic information, medical and social risk factors for TB, and clinical information about the TB case. U.S.-born persons are defined as persons born in the United States, American Samoa, the Federated States of Micronesia, Guam, the Republic of the Marshall Islands, the Commonwealth of the Northern Mariana Islands, Puerto Rico, the Republic of Palau, the U.S. Virgin Islands, and U.S. minor outlying islands, or persons born elsewhere to a U.S. citizen (3). Race/ ethnicity is self-identified. Persons of Hispanic ethnicity might be of any race or multiple races; non-Hispanic persons are categorized by race. CDC calculates state and overall national TB incidence by using July 1 midyear population estimates from the U.S. Census Bureau (3). The Current Population Survey provides the population denominators for incidence according to national origin and race/ethnicity (4). $\mathrm{TB}$ case counts and incidence per 100,000 population during 2015 and percent change from 2014 were calculated for the 50 states and DC and for each census division.

As they did during the previous 7 years, four states (California, Florida, New York, and Texas) reported $>500$ cases each in 2015 (Table 1). Together, these four states accounted for 4,839 TB cases, or approximately half (50.6\%) of all reported cases. State-specific incidence ranged from 0.5 cases per 100,000 persons (West Virginia) to $9.1 \mathrm{~TB}$ cases per 100,000 persons (Alaska) (median state incidence $=2.0$ ). By census division, the highest TB incidence was reported in the Middle Atlantic, West South Central, and Pacific divisions. The largest increases in TB incidence from 2014 to 2015 occurred in the East North Central, New England, Mountain, and West South Central divisions.

Among the 9,563 TB cases reported during 2015, 3,201 (33.5\%) occurred among U.S.-born persons, corresponding to an annual TB incidence of 1.2 per 100,000 persons. The 6,335 $\mathrm{TB}$ cases among foreign-born persons in the United States (66.2\% of the total U.S. cases) corresponded to an annual TB incidence of 15.1 per 100,000 persons (Table 2). Overall national TB incidence remained approximately 3.0 cases per 100,000 persons during 2013-2015 (Figure).

In 2015, most U.S.-born persons reported with TB were either non-Hispanic blacks (1,144 cases) or non-Hispanic whites (991 cases) (Table 2). Among U.S.-born non-Hispanic blacks, TB incidence was at an all-time low (3.3 cases per 100,000 persons). Incidence among U.S.-born non-Hispanic whites remained the lowest $(0.5$ cases per 100,000$)$. Although U.S.-born Hispanics had the third highest case count (661 cases), they had the second lowest incidence (1.8 cases per 100,000). U.S.-born Native Hawaiians/other Pacific Islanders had the highest incidence (12.7 cases per 100,000), followed by U.S.-born American Indians/Alaska

The MMWR series of publications is published by the Center for Surveillance, Epidemiology, and Laboratory Services, Centers for Disease Control and Prevention (CDC), U.S. Department of Health and Human Services, Atlanta, GA 30329-4027.

Suggested citation: [Author names; first three, then et al., if more than six.] [Report title]. MMWR Morb Mortal Wkly Rep 2016;65:[inclusive page numbers].

\section{Centers for Disease Control and Prevention \\ Thomas R. Frieden, MD, MPH, Director \\ Harold W. Jaffe, MD, MA, Associate Director for Science \\ Joanne Cono, MD, ScM, Director, Office of Science Quality}

Chesley L. Richards, MD, MPH, Deputy Director for Public Health Scientific Services

Michael F. Iademarco, MD, MPH, Director, Center for Surveillance, Epidemiology, and Laboratory Services

MMWR Editorial and Production Staff (Weekly)

Sonja A. Rasmussen, MD, MS, Editor-in-Chief

Charlotte K. Kent, PhD, MPH, Executive Editor Jacqueline Gindler, MD, Editor

Teresa F. Rutledge, Managing Editor

Douglas W. Weatherwax, Lead Technical Writer-Editor

Soumya Dunworth, PhD, Teresa M. Hood, MS, Technical Writer-Editors

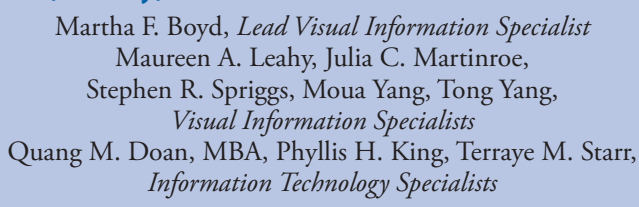
Visual Information Specialists

Quang M. Doan, MBA, Phyllis H. King, Terraye M. Starr, Information Technology Specialists

MMWR Editorial Board

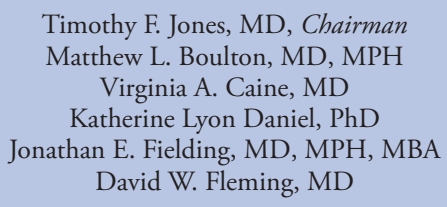

\author{
William E. Halperin, MD, DrPH, MPH \\ King K. Holmes, MD, PhD \\ Robin Ikeda, MD, MPH \\ Rima F. Khabbaz, MD \\ Phyllis Meadows, PhD, MSN, RN \\ Jewel Mullen, MD, MPH, MPA
}

\author{
Jeff Niederdeppe, $\mathrm{PhD}$ \\ Patricia Quinlisk, MD, MPH \\ Patrick L. Remington, MD, MPH \\ Carlos Roig, MS, MA \\ William L. Roper, MD, MPH \\ William Schaffner, MD
}


TABLE 1.Tuberculosis (TB) case counts and incidence, by U.S. Census division and state - United States, 2014 and 2015*

\begin{tabular}{|c|c|c|c|c|c|c|}
\hline \multirow[b]{2}{*}{$\begin{array}{l}\text { Census division/ } \\
\text { state }\end{array}$} & \multicolumn{3}{|c|}{ No. reported TB cases } & \multicolumn{3}{|c|}{$\begin{array}{l}\text { TB incidence per } \\
100,000 \text { persons }^{\dagger} \\
\end{array}$} \\
\hline & 2014 & $2015^{*}$ & $\begin{array}{c}\% \\
\text { change }\end{array}$ & 2014 & $2015^{*}$ & $\begin{array}{c}\% \\
\text { change }^{\S}\end{array}$ \\
\hline \multicolumn{7}{|c|}{ Division 1: New England } \\
\hline Connecticut & 60 & 70 & 16.7 & 1.7 & 1.9 & 16.8 \\
\hline Maine & 14 & 18 & 28.6 & 1.1 & 1.4 & 28.7 \\
\hline Massachusetts & 199 & 192 & -3.5 & 2.9 & 2.8 & -4.1 \\
\hline New Hampshire & 11 & 13 & 18.2 & 0.8 & 1.0 & 17.9 \\
\hline Rhode Island & 21 & 30 & 42.9 & 2.0 & 2.8 & 42.7 \\
\hline Vermont & 2 & 7 & 250.0 & 0.3 & 1.1 & 250.4 \\
\hline Total & 307 & 330 & 7.5 & 2.1 & 2.2 & 7.2 \\
\hline \multicolumn{7}{|c|}{ Division 2: Middle Atlantic } \\
\hline New Jersey & 307 & 326 & 6.2 & 3.4 & 3.6 & 6.0 \\
\hline New York & 784 & 766 & -2.3 & 4.0 & 3.9 & -2.5 \\
\hline Pennsylvania & 208 & 200 & -3.8 & 1.6 & 1.6 & -3.9 \\
\hline Total & 1,299 & 1,292 & -0.5 & 3.1 & 3.1 & -0.7 \\
\hline \multicolumn{7}{|c|}{ Division 3: East North Central } \\
\hline Illinois & 320 & 344 & 7.5 & 2.5 & 2.7 & 7.7 \\
\hline Indiana & 108 & 116 & 7.4 & 1.6 & 1.8 & 7.1 \\
\hline Michigan & 105 & 130 & 23.8 & 1.1 & 1.3 & 23.7 \\
\hline Ohio & 156 & 143 & -8.3 & 1.3 & 1.2 & -8.5 \\
\hline Wisconsin & 48 & 69 & 43.8 & 0.8 & 1.2 & 43.5 \\
\hline Total & 737 & 802 & 8.8 & 1.6 & 1.7 & 8.7 \\
\hline \multicolumn{7}{|c|}{ Division 4: West North Central } \\
\hline lowa & 54 & 38 & -29.6 & 1.7 & 1.2 & -30.0 \\
\hline Kansas & 40 & 36 & -10.0 & 1.4 & 1.2 & -10.3 \\
\hline Minnesota & 147 & 150 & 2.0 & 2.7 & 2.7 & 1.4 \\
\hline Missouri & 80 & 93 & 16.3 & 1.3 & 1.5 & 15.9 \\
\hline Nebraska & 38 & 33 & -13.2 & 2.0 & 1.7 & -13.8 \\
\hline North Dakota & 15 & 9 & -40.0 & 2.0 & 1.2 & -41.3 \\
\hline South Dakota & 8 & 17 & 112.5 & 0.9 & 2.0 & 111.2 \\
\hline Total & 382 & 376 & -1.6 & 1.8 & 1.8 & -2.1 \\
\hline \multicolumn{7}{|c|}{ Division 5: South Atlantic } \\
\hline Delaware & 22 & 23 & 4.5 & 2.4 & 2.4 & 3.4 \\
\hline District of Columbia & 32 & 33 & 3.1 & 4.8 & 4.9 & 1.2 \\
\hline Florida & 595 & 602 & 1.2 & 3.0 & 3.0 & -0.6 \\
\hline Georgia & 335 & 322 & -3.9 & 3.3 & 3.2 & -5.0 \\
\hline Maryland & 198 & 176 & -11.1 & 3.3 & 2.9 & -11.6 \\
\hline North Carolina & 195 & 201 & 3.1 & 2.0 & 2.0 & 2.0 \\
\hline South Carolina & 79 & 104 & 31.6 & 1.6 & 2.1 & 29.8 \\
\hline Virginia & 198 & 213 & 7.6 & 2.4 & 2.5 & 6.9 \\
\hline West Virginia & 13 & 10 & -23.1 & 0.7 & 0.5 & -22.9 \\
\hline Total & 1,667 & 1,684 & 1.0 & 2.7 & 2.7 & -0.2 \\
\hline
\end{tabular}

Natives (6.8 cases per 100,000). A total of $344 \mathrm{~TB}$ cases occurred among U.S.-born persons aged $<15$ years $(0.6$ cases per 100,000$)$, representing $10.7 \%$ of all U.S.-born persons reported as having incident TB in 2015.

In 2015, among foreign-born persons with reported TB in the United States, Asians had both the highest case count (3,007 cases) and highest incidence (28.2 cases per 100,000 persons). The top five countries of origin for foreign-born persons with TB were Mexico ( $\mathrm{n}=1,250 ; 19.7 \%)$, the Philippines $(\mathrm{n}=819 ; 12.9 \%)$, India $(\mathrm{n}=578 ; 9.1 \%)$, Vietnam $(\mathrm{n}=513$; $8.1 \%)$, and China $(n=424 ; 6.7 \%)$. Together, these countries represent $45.2 \%$ of the foreign-born population in the United States (4), but accounted for $56.6 \%$ (3,584 cases) of all TB
TABLE 1. (Continued) Tuberculosis (TB) case counts and incidence, by U.S. Census division and state — United States, 2014 and 2015*

\begin{tabular}{|c|c|c|c|c|c|c|}
\hline \multirow[b]{2}{*}{$\begin{array}{l}\text { Census division/ } \\
\text { state }\end{array}$} & \multicolumn{3}{|c|}{ No. reported TB cases } & \multicolumn{3}{|c|}{$\begin{array}{l}\text { TB incidence per } \\
100,000 \text { persons }^{\dagger}\end{array}$} \\
\hline & 2014 & $2015^{*}$ & $\begin{array}{c}\% \\
\text { change }\end{array}$ & 2014 & $2015^{*}$ & $\begin{array}{c}\% \\
\text { change }^{\S}\end{array}$ \\
\hline \multicolumn{7}{|c|}{ Division 6: East South Central } \\
\hline Alabama & 133 & 119 & -10.5 & 2.7 & 2.4 & -10.8 \\
\hline Kentucky & 80 & 67 & -16.3 & 1.8 & 1.5 & -16.5 \\
\hline Mississippi & 74 & 74 & 0.0 & 2.5 & 2.5 & 0.0 \\
\hline Tennessee & 151 & 131 & -13.2 & 2.3 & 2.0 & -13.9 \\
\hline Total & 438 & 391 & -10.7 & 2.3 & 2.1 & -11.1 \\
\hline \multicolumn{7}{|c|}{ Division 7: West South Central } \\
\hline Arkansas & 93 & 90 & -3.2 & 3.1 & 3.0 & -3.6 \\
\hline Louisiana & 121 & 119 & -1.7 & 2.6 & 2.5 & -2.1 \\
\hline Oklahoma & 59 & 67 & 13.6 & 1.5 & 1.7 & 12.6 \\
\hline Texas & 1,269 & 1,334 & 5.1 & 4.7 & 4.9 & 3.2 \\
\hline Total & 1,542 & 1,610 & 4.4 & 4.0 & 4.1 & 2.9 \\
\hline \multicolumn{7}{|l|}{ Division 8: Mountain } \\
\hline Arizona & 193 & 198 & 2.6 & 2.9 & 2.9 & 1.1 \\
\hline Colorado & 64 & 73 & 14.1 & 1.2 & 1.3 & 12.0 \\
\hline Idaho & 11 & 11 & 0.0 & 0.7 & 0.7 & -1.2 \\
\hline Montana & 6 & 9 & 50.0 & 0.6 & 0.9 & 48.6 \\
\hline Nevada & 74 & 85 & 14.9 & 2.6 & 2.9 & 12.8 \\
\hline New Mexico & 50 & 46 & -8.0 & 2.4 & 2.2 & -8.0 \\
\hline Utah & 31 & 37 & 19.4 & 1.1 & 1.2 & 17.3 \\
\hline Wyoming & 2 & 4 & 100.0 & 0.3 & 0.7 & 99.4 \\
\hline Total & 431 & 463 & 7.4 & 1.9 & 2.0 & 5.9 \\
\hline \multicolumn{7}{|l|}{ Division 9: Pacific } \\
\hline Alaska & 62 & 67 & 8.1 & 8.4 & 9.1 & 7.9 \\
\hline California & 2,134 & 2,137 & 0.1 & 5.5 & 5.5 & -0.8 \\
\hline Hawaii & 136 & 127 & -6.6 & 9.6 & 8.9 & -7.4 \\
\hline Oregon & 77 & 76 & -1.3 & 1.9 & 1.9 & -2.7 \\
\hline Washington & 194 & 208 & 7.2 & 2.7 & 2.9 & 5.6 \\
\hline Total & 2,603 & 2,615 & 0.5 & 5.0 & 5.0 & -0.6 \\
\hline Total U.S. Population & 9,406 & 9,563 & 1.7 & 2.9 & 3.0 & 0.9 \\
\hline \multicolumn{7}{|c|}{$\begin{array}{l}\text { * TB case counts are based on provisional National Tuberculosis Surveillance } \\
\text { System data as of March 4, 2016. Updated data will be available in CDC's annual } \\
\text { TB surveillance report later this year (http://www.cdc.gov/tb/statistics/). } \\
\text { † CDC calculates state and national TB incidence by using the U.S. Census } \\
\text { Bureau's July } 1 \text { midyear population estimates (http://www.census.gov/popest// } \\
\text { data/national/totals/2015/index.html). } \\
\text { §ercentage change in incidence is calculated on the basis of unrounded } \\
\text { incidence for } 2014 \text { and } 2015 \text {. }\end{array}$} \\
\hline
\end{tabular}

cases among foreign-born persons. Although Mexico-born persons accounted for the largest proportion of foreign-born persons reported with $\mathrm{TB}$, their $\mathrm{TB}$ incidence in the United States $(10.4$ cases per 100,000$)$ was lower than that among persons born in China (24.9 cases per 100,000), India (23.9 cases per 100,000), the Philippines (46.9 cases per 100,000), and Vietnam (47.8 cases per 100,000). From 2014 to 2015, the number of TB cases among Philippines-born persons grew from 755 to 819 ( $8.5 \%$ increase), and the number of TB cases among India-born persons grew from 479 to 578 (20.7\% increase). The Philippines-born population in the United States grew from 1,639,286 to 1,747,287 (population growth of $6.6 \%$ ), and the India-born population grew from $2,166,930$ to $2,421,795$ (population growth of $11.8 \%$ ) (4). 
TABLE 2. Tuberculosis (TB) case counts and incidence, by national origin and race/ethnicity — United States, 2012-2015*

\begin{tabular}{|c|c|c|c|c|c|c|c|c|}
\hline \multirow[b]{2}{*}{ U.S. population group ${ }^{\dagger}$} & \multicolumn{2}{|r|}{2012} & \multicolumn{2}{|r|}{2013} & \multicolumn{2}{|r|}{2014} & \multicolumn{2}{|c|}{$2015^{*}$} \\
\hline & No. cases & $\begin{array}{c}\text { Incidence per } \\
100,000 \text { persons }{ }^{\S}\end{array}$ & No. cases & $\begin{array}{c}\text { Incidence per } \\
100,000 \text { persons }\end{array}$ & No. cases & $\begin{array}{c}\text { Incidence per } \\
100,000 \text { persons }{ }^{\S}\end{array}$ & No. cases & $\begin{array}{c}\text { Incidence per } \\
100,000 \text { persons } \$\end{array}$ \\
\hline \multicolumn{9}{|l|}{ U.S.-born } \\
\hline Hispanic & 692 & 2.0 & 655 & 1.9 & 652 & 1.8 & 661 & 1.8 \\
\hline White, non-Hispanic & 1,272 & 0.7 & 1,100 & 0.6 & 967 & 0.5 & 991 & 0.5 \\
\hline Black, non-Hispanic & 1,345 & 4.0 & 1,250 & 3.6 & 1,183 & 3.4 & 1,144 & 3.3 \\
\hline Asian & 120 & 2.0 & 151 & 2.4 & 137 & 2.1 & 141 & 2.1 \\
\hline $\begin{array}{l}\text { American Indian/Alaska } \\
\text { Native }\end{array}$ & 145 & 6.8 & 125 & 5.7 & 117 & 5.2 & 141 & 6.8 \\
\hline $\begin{array}{l}\text { Native Hawaiian/other } \\
\text { Pacific Islander }\end{array}$ & 51 & 8.4 & 44 & 6.1 & 83 & 12.4 & 88 & 12.7 \\
\hline $\begin{array}{l}\text { Multiple or unknown } \\
\text { race/ethnicity }\end{array}$ & 33 & & 37 & & 38 & & 35 & \\
\hline Total U.S.-born" & 3,658 & 1.4 & 3,362 & 1.2 & 3,177 & 1.2 & 3,201 & 1.2 \\
\hline \multicolumn{9}{|l|}{ Foreign-born } \\
\hline Hispanic & 2,096 & 11.5 & 2,039 & 11.2 & 2,093 & 11.2 & 2,024 & 10.3 \\
\hline White, non-Hispanic & 297 & 3.7 & 322 & 4.2 & 279 & 3.6 & 258 & 3.4 \\
\hline Black, non-Hispanic & 898 & 27.7 & 836 & 24.5 & 828 & 23.6 & 845 & 22.8 \\
\hline Asian & 2,845 & 29.9 & 2,848 & 29.0 & 2,852 & 28.7 & 3,007 & 28.2 \\
\hline $\begin{array}{l}\text { Multiple, other, }{ }^{* *} \text { or } \\
\text { unknown race/ethnicity }\end{array}$ & 142 & - & 146 & - & 171 & - & 201 & - \\
\hline Total foreign-born? & 6,278 & 15.9 & 6,191 & 15.6 & 6,223 & 15.4 & 6,335 & 15.1 \\
\hline Unknown national origin & 4 & - & 9 & - & 6 & - & 27 & - \\
\hline Total United States & 9,940 & 3.2 & 9,562 & 3.0 & $9,406^{\dagger \dagger}$ & $2.9^{\dagger+}$ & $9,563^{*}$ & 3.0 \\
\hline
\end{tabular}

* Provisional National Tuberculosis Surveillance System data as of March 4, 2016. Updated data will be available in CDC's annual TB surveillance report later this year (http://www.cdc.gov/tb/statistics/).

† Persons of Hispanic ethnicity might be of any race or multiple races; non-Hispanic persons are categorized by race.

$\S$ Overall national TB incidence calculated by using July 1 midyear population estimates from the U.S. Census Bureau (http://www.census.gov/popest/data/national/ totals/2015/index.html). The Current Population Survey (http://dataferrett.census.gov) provided the population denominators for incidence according to national origin and race/ethnicity.

"I Incidence provided in the text and this table is rounded. Year-to-year TB incidence per 100,000 U.S.-born population declined $7.0 \%$ from 2011 to 2012 (from 1.46 to 1.36 cases), declined $8.8 \%$ in 2013 (to 1.24 cases), declined $6.0 \%$ in 2014 (to 1.16 cases), and increased $0.3 \%$ in 2015 (to 1.17 cases). TB incidence per 100,000 foreign-born population declined 5.9\% from 2011 to 2012 (from 16.91 to 15.90), declined 1.8\% in 2013 (to 15.61 cases), declined $1.1 \%$ in 2014 (to 15.43 cases), and declined $2.3 \%$ in 2015 (to 15.08 cases).

** Other includes a total of four persons reported as American Indians/Alaska Natives (one in 2012, two in 2013, zero in 2014, one in 2015) and a total of 51 as Native Hawaiians/other Pacific Islanders (12 in 2012, 17 in 2013, eight in 2014, 14 in 2015).

t+ The provisional number of TB cases for 2014 was 9,412, which corresponded to an incidence of 2.951 per 100,000 persons (i.e., rounded up to 3.0); the updated number of TB cases for 2014 is 9,406, which corresponds to an incidence of 2.949 cases per 100,000 persons (i.e., rounds down to 2.9).

Ninety-six TB cases occurred among foreign-born persons aged $<15$ years $(6.0$ cases per 100,000$)$, representing $1.5 \%$ of all foreign-born persons reported as having incident $\mathrm{TB}$ in the United States in 2015.

\section{Discussion}

After 2 decades of annual declines (1), TB incidence in the United States has leveled at approximately 3.0 new cases per 100,000 persons. Epidemiologic modeling suggests that even if the previously observed annual declines in the United States had been sustained, TB elimination, defined as $<1$ TB case per one million persons annually (5), would not occur by the end of this century $(\sigma)$. The determinants of this leveling in TB incidence are not yet clear; further evaluation of available data is required to understand the causes of this trend.

The 1985-1992 TB resurgence was attributed to the human immunodeficiency virus (HIV)/acquired immunodeficiency syndrome epidemic, immigration from countries with higher
TB incidence, and increased TB transmission within the United States (7). However, the proportion of TB patients coinfected with HIV has declined substantially in the United States $(5.6 \%$ of TB patients in 2015 with known HIV status were coinfected, including $7.8 \%$ of the U.S.-born), and TB incidence among U.S. foreign-born persons has continued to decline (1). In contrast, the stabilization of TB incidence among U.S.-born persons (Table 2), together with evidence provided by molecular genotyping of TB cases $(1,8)$, demonstrates that TB transmission within the United States continues to occur. The continued occurrence of TB cases among U.S.born children is further corroboration, because TB disease in a young child is a sentinel event representing recent infection $(5,7)$. Substance abuse, incarceration, and homelessness associated with TB outbreaks highlight some of the complicated case management work required on the health department frontlines of TB control (9). 
FIGURE. Tuberculosis (TB) incidence overall and among U.S.- and foreign-born persons, by year — United States, 2000-2015



* Provisional National Tuberculosis Surveillance System data as of March 4, 2016. Updated data will be available in CDC's annual TB surveillance report later this year (http://www.cdc.gov/tb/statistics/).

Effective TB control requires diagnosing cases as early as possible during the illness, thus allowing earlier airborne precautions and curative treatment to interrupt transmission $(5,9)$. An early diagnosis for a patient with infectious TB also permits a timely contact investigation, which is essential to detect and prevent additional TB cases. Recently infected contacts, particularly children, benefit greatly from treatment to avert progression to active TB disease $(5,7)$. TB prevention, timely diagnosis, and treatment completion are necessary for all groups, but especially for groups disproportionally affected by TB. Since 2003, TB incidence among Native Hawaiians/other Pacific Islanders and American Indians/Alaska Natives has remained high despite declining incidence among Hispanics and non-Hispanic Asians, whites, and blacks (1).

Two thirds of all U.S. TB cases occur among foreign-born persons, often years after arrival (10), which is consistent with disease progression following years of untreated latent TB infection. Epidemiologic modeling indicates that eliminating the threat of TB in the United States will require additional strategies to reduce $\mathrm{TB}$ in the countries of origin and expand treatment of latent TB infection among the foreign-born persons (G). Despite recent declines in TB incidence among foreign-born persons, these persons continue to have a higher risk for $\mathrm{TB}$, reflecting the importance of further intensifying the global battle against TB and underscoring the importance of interventions to screen and treat U.S.-bound permanent immigrants and refugees for TB disease. TB elimination will require both global interventions and a substantial improvement in larger scale identification and treatment of latent TB infection among foreign-born persons living in the United States (G), consistent with CDC's strategic plan for the national elimination of TB (http://www.cdc.gov/tb/about/strategicplan.htm).

TB is preventable and curable, and its elimination would have widespread health, economic, and social benefits. Resuming declines in TB incidence will require more comprehensive public health approaches, both globally and domestically. These include increasing case detection and cure rates globally, reducing TB transmission in institutional settings such as health care settings and correctional facilities, and increasing detection and treatment of preexisting latent $\mathrm{TB}$ infection among the U.S. populations most affected by TB. Finally, more emphasis should be placed on interrupting the relatively limited, but persistent, ongoing TB transmission (e.g., among persons experiencing homelessness) in the United States, as well 


\section{Summary}

What is already known about this topic?

Uniform national reporting of tuberculosis (TB) cases in the United States began in 1953. During 1993-2012, the annual incidence of reported TB cases has always been $\geq 0.2$ cases per 100,000 persons lower than the previous year.

What is added by this report?

Preliminary data for 2015 indicate an incidence of 3.0 cases per 100,000 persons, approximately the same incidence as during 2013 and 2014. After 2 decades of declining incidence, progress toward TB elimination in the United States appears to have stalled.

What are the implications for public health practice?

Resuming declines in TB incidence in the United States will require intensification of efforts both domestically and globally. More emphasis should be placed on strengthening U.S. systems for detecting and treating latent TB infection and interrupting TB transmission, as well as accelerating reductions in TB globally.

as continuing research on better means to diagnose, treat, and prevent $\mathrm{TB}$ infection and disease.

This report is limited to provisional National Tuberculosis Surveillance System data as of March 4, 2016. Updated data will be available in CDC's annual TB surveillance report (1) later this year (http:/www.cdc.gov/tb/statistics/), although the final TB case count is not expected to change substantially.

\section{Acknowledgments}

State, local, tribal, and territorial health department personnel for collecting and submitting data for the National Tuberculosis Surveillance System; Cynthia Adams, Glenda Newell, Stacey Parker, Jeanette Roberts, and Katrina Williams and C. Kay Smith for technical and editing assistance, respectively, National Center for HIV/AIDS, Viral Hepatitis, STD, and TB Prevention, CDC.
${ }^{1}$ Epidemic Intelligence Service, CDC; ${ }^{2}$ Division of Tuberculosis Elimination,
National Center for HIV/AIDS, Viral Hepatitis, STD, and TB Prevention, CDC.

Corresponding authors: Jorge L. Salinas, jsalinas@cdc.gov, 404-718-8866; Godwin Mindra, GMindra@cdc.gov, 404-718-8287.

\section{References}

1. CDC. Reported tuberculosis in the United States, 2014. Atlanta, GA: US Department of Health and Human Services, CDC; 2015. http:// www.cdc.gov/tb/statistics/reports/2014/default.htm

2. CDC. Tuberculosis (TB) (Mycobacterium tuberculosis) 2009 case definition. Atlanta, GA: US Department of Health and Human Services, CDC; 2015. http://wwwn.cdc.gov/nndss/conditions/tuberculosis/ case-definition/2009/

3. US Census Bureau. Current estimates data. Washington, DC: US Census Bureau; 2016. http://www.census.gov/popest/data/national/totals/2015/ index.html

4. US Census Bureau. The DataWeb: DataFerret. Washington, DC: US Department of Commerce, US Census Bureau; undated. http:// dataferrett.census.gov/

5. Taylor Z, Nolan CM, Blumberg HM; American Thoracic Society; CDC; Infectious Diseases Society of America. Controlling tuberculosis in the United States. Recommendations from the American Thoracic Society, CDC, and the Infectious Diseases Society of America. MMWR Recomm Rep 2005;54(RR-12).

6. Hill AN, Becerra J, Castro KG. Modelling tuberculosis trends in the USA. Epidemiol Infect 2012;140:1862-72. http://dx.doi.org/10.1017/ S095026881100286X

7. Cantwell MF, Snider DE Jr, Cauthen GM, Onorato IM. Epidemiology of tuberculosis in the United States, 1985 through 1992. JAMA 1994;272:535-9. http://dx.doi.org/10.1001/jama.1994.03520070055038

8. France AM, Grant J, Kammerer JS, Navin TR. A field-validated approach using surveillance and genotyping data to estimate tuberculosis attributable to recent transmission in the United States. Am J Epidemiol 2015;182:799-807. http://dx.doi.org/10.1093/aje/kwv121

9. Haddad MB, Mitruka K, Oeltmann JE, Johns EB, Navin TR. Characteristics of tuberculosis cases that started outbreaks in the United States, 2002-2011. Emerg Infect Dis 2015;21:508-10. http://dx.doi. org/10.3201/eid2103.141475

10. Baker BJ, Winston CA, Liu Y, France AM, Cain KP. Abrupt decline in tuberculosis among foreign-born persons in the United States. PLoS One 2016;11:e0147353. http://dx.doi.org/10.1371/journal.pone.0147353 